\title{
Creatine deficiency and heart failure
}

\author{
Annamaria Del Franco ${ }^{1}$ - Giuseppe Ambrosio ${ }^{2}$. Laura Baroncelli3 ${ }^{3,4}$. Tommaso Pizzorusso ${ }^{3,5}$. Andrea Barison ${ }^{6}$. \\ lacopo Olivotto $^{7}$. Fabio A. Recchia ${ }^{1,8}$. Carlo M. Lombardi ${ }^{9} \cdot$ Marco Metra $^{9} \cdot$ Yu F. Ferrari Chen ${ }^{6} \cdot$ Claudio Passino $^{1,6}$. \\ Michele Emdin ${ }^{1,6} \cdot$ Giuseppe Vergaro ${ }^{1,6}$
}

Accepted: 8 September 2021 /Published online: 7 October 2021

(c) The Author(s) 2021

\begin{abstract}
Impaired cardiac energy metabolism has been proposed as a mechanism common to different heart failure aetiologies. The energy-depletion hypothesis was pursued by several researchers, and is still a topic of considerable interest. Unlike most organs, in the heart, the creatine kinase system represents a major component of the metabolic machinery, as it functions as an energy shuttle between mitochondria and cytosol. In heart failure, the decrease in creatine level anticipates the reduction in adenosine triphosphate, and the degree of myocardial phosphocreatine/adenosine triphosphate ratio reduction correlates with disease severity, contractile dysfunction, and myocardial structural remodelling. However, it remains to be elucidated whether an impairment of phosphocreatine buffer activity contributes to the pathophysiology of heart failure and whether correcting this energy deficit might prove beneficial. The effects of creatine deficiency and the potential utility of creatine supplementation have been investigated in experimental and clinical models, showing controversial findings. The goal of this article is to provide a comprehensive overview on the role of creatine in cardiac energy metabolism, the assessment and clinical value of creatine deficiency in heart failure, and the possible options for the specific metabolic therapy.
\end{abstract}

Keywords Creatine $\cdot$ Creatine deficiency $\cdot$ Cardiac energy metabolism $\cdot$ Heart failure

Michele Emdin

emdin@ftgm.it; m.emdin@santannapisa.it

1 Institute of Life Sciences, Scuola Superiore Sant'Anna, Pisa, Italy

2 Division of Cardiology, School of Medicine, University of Perugia, Perugia, Italy

3 Institute of Neuroscience, National Research Council (CNR), Pisa, Italy

4 Department of Developmental Neuroscience, IRCCS Stella Maris Foundation, Calambrone, PI, Italy

5 Department of Neuroscience, Drug Research, and Child Health (NEUROFARBA), University of Florence, PsychologyFlorence, Italy

6 Division of Cardiology and Cardiovascular Medicine, Fondazione Toscana Gabriele Monasterio, Pisa, Italy

7 Cardiomyopathy Unit, Azienda Ospedaliera Universitaria Careggi, Florence, Italy

8 Lewis Katz School of Medicine, Cardiovascular Research Center, Temple University, Philadelphia, PA, USA

9 Department of Medical and Surgical Specialties, Radiological Sciences and Public Health, University and Civil Hospital, Brescia, Italy

\section{Abbreviations}

$\begin{array}{ll}\text { ADP } & \text { Adenosine diphosphate } \\ \text { ATP } & \text { Adenosine triphosphate } \\ \text { AGAT } & \text { L-arginine:glycine amidinotransferase } \\ \text { Cr } & \text { Creatine } \\ \text { CK } & \text { Creatine kinase } \\ \text { CrT } & \text { Creatine transporter } \\ \text { GA } & \text { Guanidinoacetate } \\ \text { GAMT } & \text { S-adenosyl-L-methionine:guanidinoacetate } \\ & \text { N-methyltransferase } \\ \text { HF } & \text { Heart failure } \\ \text { MRS } & \text { Magnetic resonance spectroscopy } \\ \text { PCr } & \text { Phosphocreatine }\end{array}$

\section{Biochemistry of creatine}

Creatine $(\mathrm{Cr})$ is a guanidino compound that plays a vital role in the energy metabolism of cells. Cr kinase (CK) catalyses the reversible conversion of $\mathrm{Cr}$ and adenosine triphosphate (ATP) to phosphocreatine (PCr) and adenosine diphosphate. Many cells do not rely on ATP/adenosine diphosphate free diffusion and the $\mathrm{CK} / \mathrm{PCr} / \mathrm{Cr}$ system servers as energy 
storage for immediate regeneration of ATP and as a shuttle of high-energy phosphate between the mitochondrial site of ATP production and cytosolic sites of ATP consumption [1] (Fig. 1). Specifically, the CK/PCr system serves 3 major functions: "temporal" energy buffer, employing $\mathrm{PCr}$ and $\mathrm{Cr}$ to maintain adequate ATP concentrations; "spatial" energy buffer, creating tightly coupled connections between ATPproducing and ATP-consuming processes; and regulation of metabolic pathways. Under physiological conditions, the CK system is predominant and provides about two-thirds of the energy transfer, whereas the direct adenine nucleotide channelling contributes only to one-third [2]. Accordingly, $\mathrm{Cr}$ is particularly abundant in tissues with high and intermittent energy fluctuations, such as skeletal muscle, heart, and brain [1].
$\mathrm{Cr}$ is endogenously synthesized and absorbed from dietary sources, then mainly stored in muscles. Endogenous biosynthesis involves 2 sequential steps: first, the transfer of an amidino group from arginine to glycine, catalysed by L-arginine:glycine amidinotransferase (AGAT), yields the intermediate guanidinoacetate (GA); GA is then converted into $\mathrm{Cr}$ via the enzyme S-adenosyl-Lmethionine:guanidinoacetate N-methyltransferase (GAMT) [3] (Fig. 2). GA is primarily produced in the kidney and methylated to $\mathrm{Cr}$ in the liver; then, $\mathrm{Cr}$ is released in the bloodstream to be delivered throughout the body [3]. $\mathrm{Cr}$ is a polar hydrophilic molecule unable to cross the plasma membrane; hence, it requires a specific $\mathrm{Na}^{+} / \mathrm{Cl}^{-}$-dependent transporter (Cr transporter, CrT; solute carrier, SLC6A8) to enter the cells [4]. Cr transport is largely regulated by

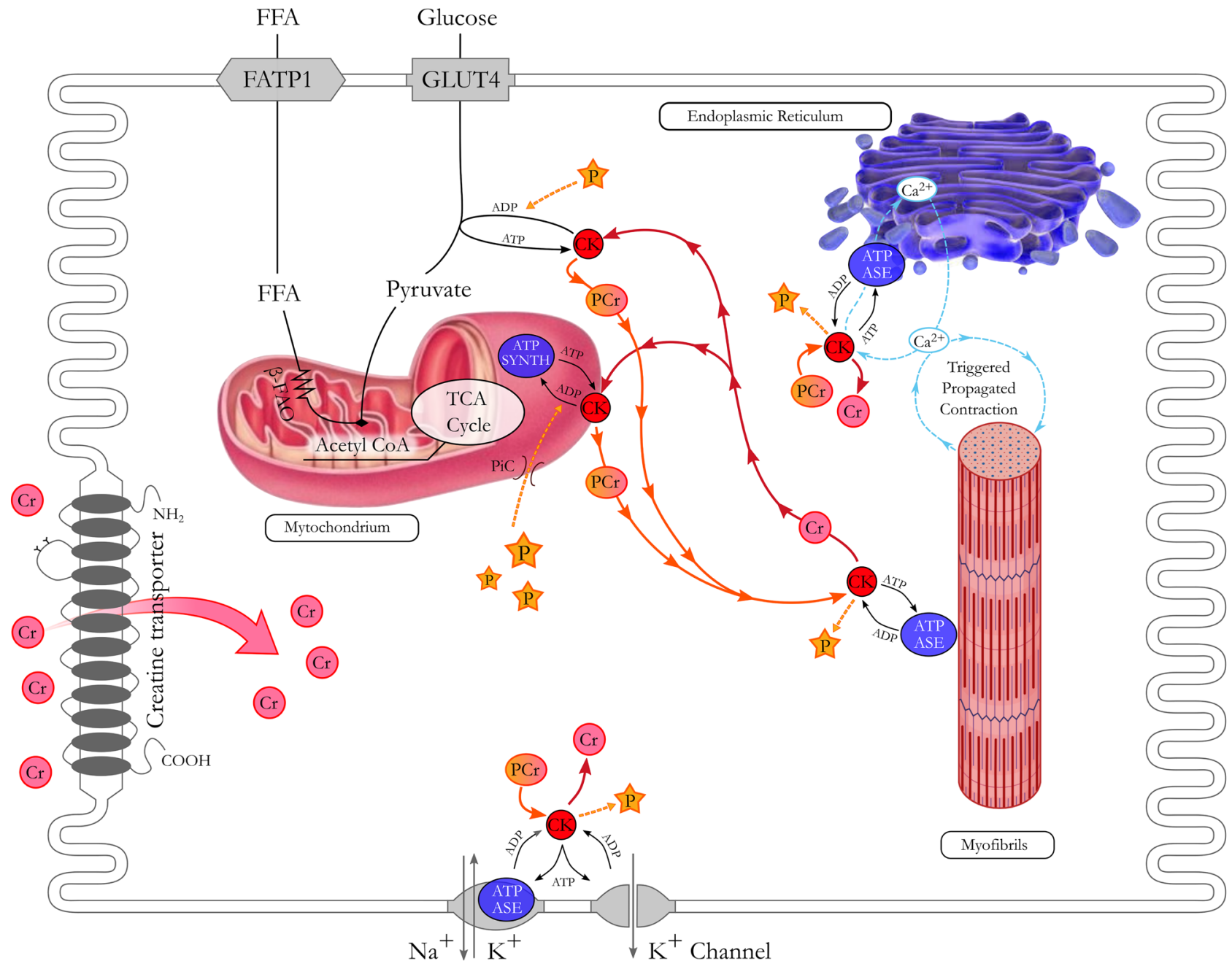

Fig. 1 Role of creatine in the cardiomyocyte. A specific carrier (CrT) mediates creatine $(\mathrm{Cr})$ uptake from bloodstream into cardiomyocytes. $\mathrm{Cr}$ links adenosine triphosphate (ATP) production site to energy utilization sites, like myofibrils and ion pumps. Phosphocreatine (PCr) acts as a highly mobile and short-term energy store. After releasing the phosphate group to generate ATP thanks to the cytosolic cre- atine kinases (CK) closely coupled to ATPases, free $\mathrm{Cr}$ diffuses back to request further ATP production. $\beta$-FAO beta fatty acid oxidation, FATP1 fatty acid transport protein 1, FFA free fatty acid, GLUT4 glucose transporter type 4, PiC mitochondrial phosphate carrier, TCA tricarboxylic acid 


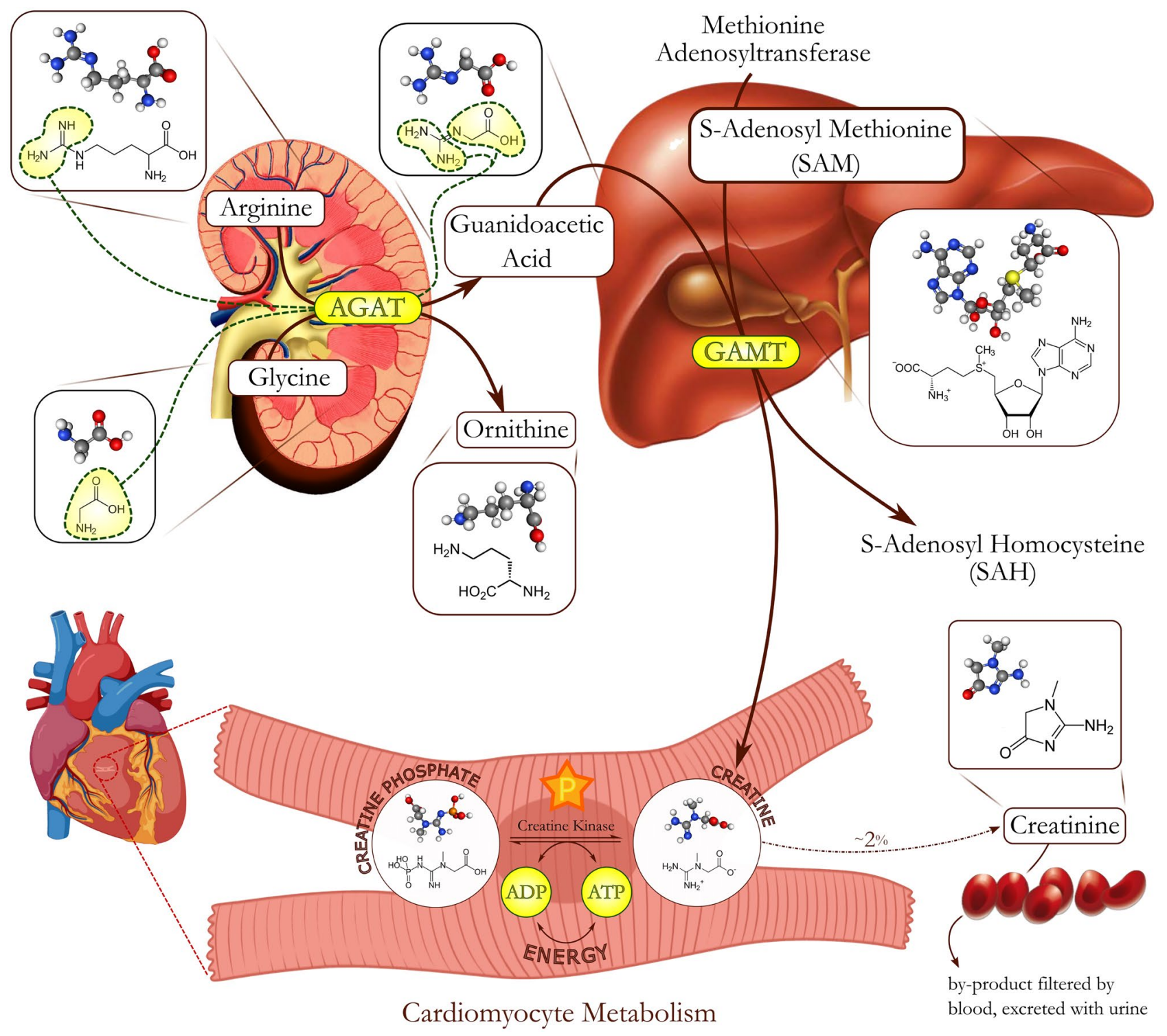

Fig. 2 Creatine biosynthesis. Creatine 2-step biosynthesis: the transfer of an amidino group from arginine to glycine, catalysed by L-arginine:glycine amidinotransferase (AGAT), yields the guanidinoacetate (GA); GA is converted into $\mathrm{Cr}$ via the enzyme S-adenosylL-methionine:guanidinoacetate $\mathrm{N}$-methyltransferase (GAMT). The

substrate availability: the increase in extracellular $\mathrm{Cr}$ content reduces the rate of $\mathrm{Cr}$ uptake, whereas decreased intracellular $\mathrm{Cr}$ content increases $\mathrm{Cr}$ transport. Although there is a unique CrT protein, its modulation is complex and tissuespecific. With this regard, thioredoxin interacting protein has been identified as an important negative-feedback regulator, acting as a promoter of intracellular $\mathrm{Cr}$ concentration [5]. Furthermore, supporting the idea that $\mathrm{Cr}$ transport might be modulated by pathways that respond to changes in the overall cellular metabolic state, 5-AMP-activated protein kinase has shown to be a positive and physiological regulator of $\mathrm{Cr}$ first step occurs in the kidney, the second in the liver. $\mathrm{Cr}$ and phosphocreatine (PCr), together with creatine kinase (CK), constitute an energy shuttle system. $\mathrm{Cr}$ degrades into creatinine, excreted by the kidney

transport, ensuring sufficient quantities of $\mathrm{Cr}$ and supporting myocellular function [6]. Similarly, several analyses in murine models have shown that in cardiac muscle, modulation of $\mathrm{Cr}$ transport capacity is primarily regulated by posttranslational modifications of $\mathrm{CrT}$ protein, rather than by transcriptional changes [7].

Finally, $\mathrm{Cr}$ and $\mathrm{PCr}$ are subject to a slow, non-enzymatic, and unregulated dehydration and cyclisation yielding creatinine (about $1.7 \%$ of $\mathrm{Cr} / \mathrm{PCr}$ body pool): this end-product freely diffuses out the cell to be ultimately removed with urine. 


\section{Physiology of creatine and phosphocreatine in cardiomyocytes}

Chemical energy in the form of ATP is produced from multiple substrates (principally long-chain fatty acids, lactate, and glucose), predominantly in the mitochondria via oxidative phosphorylation. To ensure that energy is readily available at sites of utilization, a phosphagen system is required, consisting in the reversible interaction of $\mathrm{Cr}$ and ATP under the control of CK enzymes [8]. Tissueand cell-specific CK isoforms are well known. At cardiac level, muscle-type CK and mitochondrial CK are the most represented [9]. Mitochondrial CK catalyses direct transfer of a high-energy phosphoryl group from ATP to $\mathrm{Cr}$ to form $\mathrm{PCr}$, acting as a highly mobile, short-term energy store, as it is smaller and less polar than ATP [3]. The reverse reaction is catalysed by the cytosolic CK dimers and generates ATP; then, the free Cr diffuses back to signal the need for further ATP production [9].

In addition to its role in ATP regeneration, $\mathrm{PCr}$ acts as membrane stabilizer [10]. PCr may therefore promote the transition of the mobile domain of membranes into a structured phase, leading to a decreased rate of phospholipids degradation into lysophospholipids and lipid peroxidation. This second mechanism is particularly relevant for cardiac function, since the $\mathrm{PCr} / \mathrm{Cr}$ plays a protective role against ischaemic insults [10].

\section{Assessment of cardiac creatine metabolism}

Magnetic resonance spectroscopy (MRS) is the only technique capable to non-invasively measure the ratios and concentrations of endogenous cardiac high-energy phosphate metabolites and CK flux in human hearts. Cardiac MRS is a challenging technique, since the heart is constantly in motion (ECG-gating, breath-holding) and due to the very low concentration of nuclei of interest $\left({ }^{31} \mathrm{P},{ }^{13} \mathrm{C}\right)$ if compared to ${ }^{1} \mathrm{H}$.

MRS has been first technology employed to obtain the measure of myocardial PCr/ATP ratio [11]. MRS can be used to measure the absolute concentrations of $\mathrm{PCr}$ and ATP, the CK reaction rate, and flux [12] by assessing phosphorus $\left({ }^{31} \mathrm{P} \mathrm{MRS}\right)$, as well as to measure total $\mathrm{Cr}$ pool by assessing proton $\left({ }^{1} \mathrm{H}\right.$ MRS) [13]. Combining $31 \mathrm{P}$ and $1 \mathrm{H}$ MRS, it is possible to characterize CK metabolism in the healthy and diseased human heart [14].

The PCr/ATP ratio has been used as a marker of cardiac energetic status in heart failure (HF). Specifically, PCr level decreases in the initial phase, whereas ATP level decreases only in advanced stages of HF. Myocardial PCr, $\mathrm{Cr}$, and $\mathrm{CK}$ enzyme levels are consistently low in $\mathrm{HF}$, and can precede cardiac dysfunction [15], while they are preserved in other heart diseases such as ischaemic heart disease [11]. The PCr/ATP ratio, however, is not affected when proportional changes in both PCr and ATP concentrations occur. Beer and colleagues [16] observed that $\mathrm{PCr}$ and ATP concentrations are both reduced in dilated cardiomyopathy, although with a greater reduction in $\mathrm{PCr}$ than in ATP. Thus, the PCr/ATP ratio alone may underestimate the extent of changes in high-energy phosphate levels, especially during the earlier stages of HF. Furthermore, experimental studies have earlier documented that the assessment of PCr and ATP cardiac concentrations might provide little information at the steady-state. In fact, if the energy machinery remains functional, as in the "stunned" heart, $\mathrm{PCr}$ and ATP can be re-synthesized at a suitable rate to support an increased demand [17].

Since the PCr/ATP ratio cannot provide reliable information about the effective availability of high energy phosphates, other MRS indexes were developed. The product of the pseudo-first-order forward reaction-rate constant for the $\mathrm{CK}$ reaction $(\mathrm{kf})$ and the $\mathrm{PCr}$ concentration (CK flux) allows the measurement of the forward rate of ATP synthesis through CK system [18] (Fig. 3). Studies combining assessment of PCr and ATP concentration and CK flux demonstrated in non-ischaemic dilated cardiomyopathy not only that $\mathrm{PCr}$ concentration is reduced, but also that the reduction in CK flux ( $\sim 35$ to $70 \%)$ is greater than the reduction in the PCr/ATP ratio ( $\sim 10$ to $20 \%$ ) [12]. Thus, the reduced ATP supplied by the CK reaction, rather than the increase in adenosine diphosphate (ADP) concentration, might contribute to the dysfunction. Another study showed that only CK flux is capable of predicting outcomes in non-ischaemic dilated cardiomyopathy [19]. Additionally, the loss in CK energy reserve matches the reduction in mechanical efficiency, pointing to inadequate energy supply as a potential contributor to the contractile dysfunction observed in mildto-moderate HF. Finally, since CK flux reduction is more pronounced than PCr/ATP ratio reduction [12], it seems more reliable and accurate in predicting outcomes and mortality even in earlier stages of HF [20].

The severity of the energetic deficit was also evaluated by determining the free energy of ATP hydrolysis, which is the driving force that powers cellular ATP-requiring processes. The quantification in vivo of cardiac Pi concentration by higher-field MRS systems allows the calculation of ATP hydrolysis. In failing heart, the decrease in $\mathrm{Cr}$ concentration is initially thought to be a compensatory mechanism counteracting the expected increase in cytosolic ADP, with consequent preservation of the free energy of ATP hydrolysis [21]. However, in the scenario of high ATP consumption, such as during exercise or stress, once CK activity is decreased, the higher ATP and ADP fluctuations reduce the 


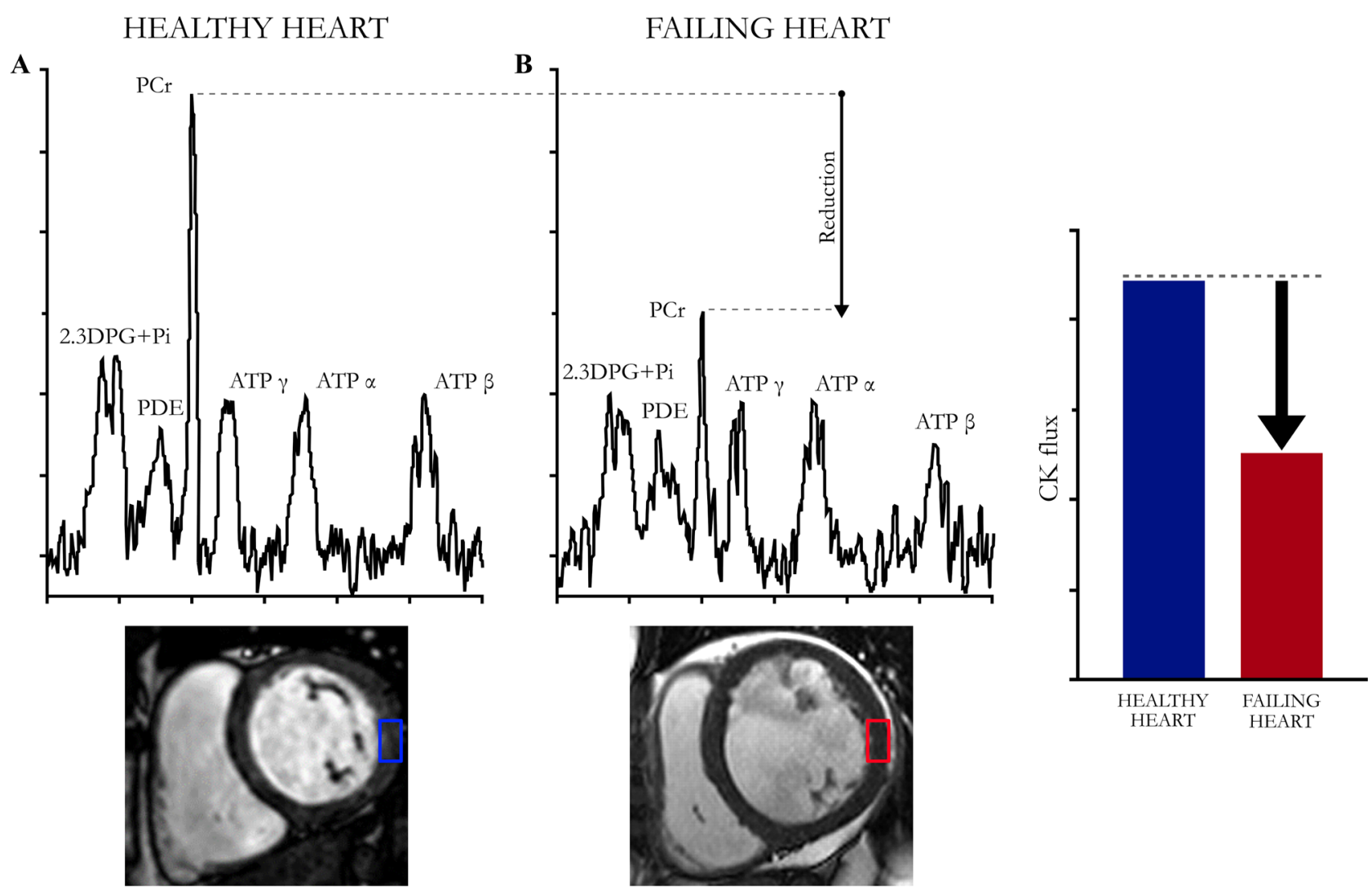

Fig. 3 31P magnetic resonance spectroscopy (MRS) cardiac evaluation. Characteristic cardiac 31P MRS spectra in A a healthy and B failing heart. In the pathological condition, $\mathrm{PCr}$ concentration and CK flux are reduced

energy available from ATP hydrolysis, limiting the maximum available energy during peak demand [22].

MRS use is currently limited to research purposes, but it might improve our understanding of the pathophysiology of several cardiac conditions. Technical advances are still required for the clinical use of cardiac MRS.

\section{Creatine deficiency in heart failure}

According to the energy starvation hypothesis, altered myocardial metabolism anticipates and sustains contractile dysfunction [23]. The healthy heart has a high capacity for ATP turnover and, during exercise, cardiac output and $\mathrm{O}_{2}$ consumption may rise up to sixfold. This functional reserve is granted by a considerable number of mitochondria, balancing the limited amount of stored ATP and of phosphotransfer systems. In HF, contractile reserve is limited both by an impairment of $\mathrm{PCr} / \mathrm{CK}$ system [24] and by mitochondrial dysfunction [25].

Decreased cardiac $\mathrm{Cr}$ content and total $\mathrm{CK}$ activity are observed in HF regardless of underlying aetiology, prominently in advanced stages [26]. Additionally, low $\mathrm{PCr}$ is an early indicator of an energetic deficit [24] and $\mathrm{PCr} / \mathrm{ATP}$ ratio is associated with more severe HF symptoms [11], low contractile function, and myocardial structural remodelling [27], proving to be an excellent predictor of cardiovascular mortality in patients with dilated cardiomyopathy [28]. Cr loss is likely to occur secondary to a reduced expression of the CrT [29]. However, it is not completely clear to what extent the reduced PCr buffer activity contributes to the pathophysiology of HF and if a correction of this energetic deficit would prove beneficial.

The functional role of high-energy phosphate metabolism in HF should be investigated focusing on the depletion of myocardial $\mathrm{PCr}$ and $\mathrm{Cr}$ levels. A way to achieve that condition could be by means of a pharmacological compound known to specifically reduce $\mathrm{PCr}$ and $\mathrm{Cr}$ in the heart, the $\beta$-guanidinopropionate. Specifically, $\beta$-guanidinopropionate is a $\mathrm{Cr}$ analogue that is taken up by the cardiomyocyte via the $\mathrm{CrT}$ and is then phosphorylated, causing the inhibition of CK reaction [30]. In normal heart, the depletion of $\mathrm{PCr}$ and $\mathrm{Cr}$ due to $\beta$-guanidinopropionate treatment impaired the capability of CK system to ensure high levels of sustained contractile function [31]. In ischaemic condition, the $\beta$-guanidinopropionate-induced depletion of $\mathrm{PCr}(65 \%)$ and 
reduction of CK flux (75\%) make the heart unable to overcome the stress of an acute myocardial infarction; specifically, this finding might be due either to the remaining intact myocardium not being able to face the acute haemodynamic stress or to the induction of fatal ventricular arrhythmias or both. However, chronic $\mathrm{PCr}$ and $\mathrm{Cr}$ depletion, obtained by $\beta$-guanidinopropionate treatment started after the recovery from coronary ligation, did not further impair myocardial performance, suggesting an adaptation of the chronically failing heart and highlighting the functional relevance of the PCr-CK system only in acutely induced HF [32]. However, $\beta$-guanidinopropionate has many limitations such as off-target effects, slow and incomplete creatine depletion, and the ability to partially compete in the creatine kinase reaction [33].

Genetically manipulated mouse models circumvent limitations of $\beta$-guanidinopropionate and provide a more accurate approach to assess the functional significance of the $\mathrm{PCr} / \mathrm{CK}$ system. In particular, genetic loss-of-function mice have been described for all CK isoforms, for Cr-related enzymes (AGAT, GAMT) and for CrT. Even if muscle/mitochondrial $\mathrm{CK}^{-/}$mice show elevated end-diastolic pressure, impaired contractility, and pulmonary congestion [34], a primary deficiency of CK system does not determine per se an overt HF [35], but rather a cardiac phenotype that can be unmasked during acute stress conditions. Moreover, a genetically determined reduction of CK function is likely to result in long-term compensatory adaptations, which cannot be set during acute cardiac damage [34]. Cardiac functions of AGAT and GAMT have been studied in global knockout mice, since these enzymes are not expressed in the heart. In the $\mathrm{AGAT}^{-/-}$model, only low LV systolic pressure seems to be related to $\mathrm{Cr}$ depletion, whereas other haemodynamic alterations such as the reduced inotropy and the impaired contractile reserve are rescued after homoarginine supplementation [36]. Similarly, GAMT ${ }^{-/-}$model shows only a small reduction in LV systolic pressure and an impaired contractile reserve at baseline [37]; these alterations do not have consequences in terms of exercise performance and of cardiac function after myocardial infarction in Cr-deficient condition [38]. In particular, if the unaltered cardiac function at "resting" condition suggests that the $\mathrm{CK} / \mathrm{PCr}$ system does not play a crucial role in maintaining cardiac performance under low workload, on the opposite, the absence of a high-capacity $\mathrm{CK} / \mathrm{PCr}$ system seems to aggravate myocardial injury in case of acute myocardial stress due to energy demand/supply mismatch [37]. These findings suggest a possible redundancy of energy buffer and transfer systems at baseline and low workload. In fact, $\mathrm{GAMT}^{-/-}$mice receiving a Cr-free diet accumulate GA, which can potentially compensate the $\mathrm{Cr}$ deficiency by participating in the $\mathrm{CK}$ reaction [38].
Mechanisms underlying the compensatory condition and their long-lasting effects are under investigation. There is evidence that 18 months old GAMT $^{-1-}$ mice have reduced rates of contractility and relaxation [39]. This finding is not clearly related to the Cr deficiency or the to the GA toxicity, but might suggest that adaptations observed in young mice are subject to age-related decline [39].

The phenotypic characteristics at cardiac level of a $\mathrm{CrT}^{-/ y}$ murine model have not been described yet, despite a reduced cardiac $\mathrm{Cr}$ concentration has been shown [40]. While $\mathrm{Cr}$ supplementation is not effective to increase intracellular $\mathrm{Cr}$ content due to the downregulation of $\mathrm{CrT}$, the augmentation of the CrT activity is expected to be beneficial [8]. Increasing myocardial $\mathrm{Cr}$ levels by $20-100 \%$, via overexpression of the plasma membrane $\mathrm{CrT}$, protects the murine heart against ischaemia/reperfusion injury through the improvement in energy reserves and increased $\mathrm{PCr}$ and glycogen levels [41]. However, no benefit in terms of cardiac remodelling and function was detected in a model of post-myocardial infarction chronic HF. Moreover, in case of very high cardiac $\mathrm{Cr}$ concentrations exceeding $100 \%$ of total increase, severe cardiac hypertrophy and dysfunction are reported [42].

In conclusion, the $\mathrm{PCr}-\mathrm{CK}$ system seems essential for supporting the function of hearts in healthy and in high energy demand or acute stress, whereas it loses its importance in chronic condition, probably due to the emergence of compensatory mechanisms. The interruption of a single step of the metabolic chain is probably not sufficient to mimic the complex interactions occurring in chronic HF.

\section{Exercise training and creatine kinase system}

Training increases exercise capacity, quality of life, and reduces morbidity and mortality in HF by improving endothelial function and coronary perfusion, decreasing peripheral resistance and ventricular remodelling, as well as neuro-endocrine and pro-inflammatory activation [43].

The positive effects of exercise on cardiac energy metabolism, in particular on the $\mathrm{Cr}$ system, are not well-understood. An improvement in oxidative capacity and a restoration of CK activity after exercise training has been reported [44], confirming that the CK system actively takes part to the intracellular metabolism. On the opposite, GAMT knockout mice display exercise performance and survival similar to wild type mice [38], questioning if $\mathrm{Cr}$ is essential for high workload and chronic stress responses in heart and skeletal muscle.

Although preliminary evidence exists supporting an improvement in pro-inflammatory drive and endothelial dysfunction by the combination of $\mathrm{Cr}$ supplementation and regular exercise [45], further investigations are needed. 


\section{Pharmacological approaches to improve cardiac metabolism in heart failure}

Neurohormonal antagonists are the cornerstone of pharmacological therapy of HF. Since neuro-hormonal activation significantly contributes to the metabolic inefficiency of the heart [46], an indirect beneficial effect of neurohormonal antagonists on energy efficiency might be expected. However, although both beta-blockers and angiotensin-converting enzyme inhibitors increase $\mathrm{PCr}$ content, $\mathrm{CK}$ reaction velocity and mitochondrial $\mathrm{CK}$ activities also reduce free fatty acid availability, a state of low metabolic efficiency in both skeletal and cardiac muscles still persists in HF [47].

Pharmacological modulation of cardiac metabolism in HF was proposed in the early 1990s [48], based on 3 mechanisms: reduction of ATP availability, decreased ATP transfer and availability to the myofibrils, and reduction of the free energy change of ATP hydrolysis.

Options to modify substrate utilization, shifting the myocardial substrate from free fatty acid metabolism to glucose metabolism, have been largely investigated [49]. Myocardial glucose oxidation can be achieved either directly with stimulation of glucose metabolism, or indirectly through inhibition of fatty acid beta-oxidation. Trimetazidine inhibits fatty acid oxidation by blocking 3-ketoacyl-coenzyme A thiolase and preserves myocardial high-energy phosphate intracellular levels [50, 51]. Similarly, ranolazine enhances myocardial utilization of glucose and significantly improves LV performance in experimental models of HF [52].

$\mathrm{Cr}$ supplementation showed to improve skeletal muscle mass and strength in chronic HF, while cardiac contractility was not affected [53], despite $\mathrm{Cr}$ induces better adaptive physiological responses mediated by hypoxia-inducible factor- 1 and by the subsequent rise of cellular ATP and $\mathrm{PCr}$ content [54, 55]. Fumagalli et al. demonstrated an improvement in total work capacity and peak oxygen consumption validating the positive effect of supplementation of $\mathrm{Cr}$ in combination with coenzyme Q10, which however could be related to the beneficial effect on the diseased skeletal muscle rather than to a direct action on the myocardium [56]. With this regard, in the history of treatment strategies for $\mathrm{HF}$ - a status characterized by muscle wasting and cachexia - the improvement of clinical status by enhancing muscular performance has also been noticed in case of other micronutrients, hence, the idea of a multiple micronutrient approach or a combination of nutrient supplementation and exercise training [57]. In fact, Hemati and colleagues showed that the combination of $\mathrm{Cr}$ monohydrate and exercise attenuates inflammation and endothelial dysfunction markers in HF [45].

The unknown mechanisms regulating the organ distribution of the total $\mathrm{Cr}$ pool could explain the lack of effect of $\mathrm{Cr}$ supplementation on surrogate markers of cardiac performance. The energy-demanding heart has a lower $\mathrm{Cr}$ intake compared to the liver. Further, tissues with high baseline $\mathrm{Cr}$ (i.e. heart) have less loading potential than tissues with low $\mathrm{Cr}$ (i.e. liver), possibly as a consequence of CrT inhibition.

The questionable results concerning the benefits of $\mathrm{Cr}$ therapy in HF might also be related to the use of the sole $\mathrm{Cr}$ monohydrate, whether other $\mathrm{Cr}$ forms are known to be more efficient in terms of bioavailability and tolerability [58]. Furthermore, an indirect benefit could derive from supplementation of other components of the $\mathrm{Cr}$ synthesis production chain, such as L-arginine that proved to be efficacious in augmenting peripheral blood flow and improving functional status in a small cohort of HF patients [59].

Exogenous $\mathrm{PCr}$ has gained considerable attention as an effective and safe protective agent in different clinical settings, including cardiac surgery, myocardial infarction, and HF [60]. Treatment with PCr in patients with acute and chronic heart diseases might reduce all-cause shortterm mortality and is associated with an improvement in left ventricular ejection fraction in chronic HF and with a decrease in arrhythmic complications and left ventricular remodelling in patients undergoing cardiac surgery [61] (Central illustration). However, $\mathrm{PCr}$ studies are based on a small population and with the absence of long-term follow up [60]. The cardiac effect of $\mathrm{PCr}$ supplementation might be dependent on the route of administration, as intravenous route appears to be the only yielding significant and longlasting $\mathrm{Cr}$ elevation in myocardium. Moreover, differently from $\mathrm{Cr}$, $\mathrm{PCr}$ is not carried within the cell by CrT; it does not easily cross membranes and its intracellular levels do not modulate CrT activity [62].

An overview of the principal clinical studies on $\mathrm{Cr}$ and $\mathrm{PCr}$ supplementation is illustrated in Table 1.

Chemically modified, highly lipophilic $\mathrm{Cr}$ (cyclocreatine or $\mathrm{Cr}$ esters) may exploit passive diffusion across the plasmatic membrane and overcome the CrT downregulation related to an elevated intracellular $\mathrm{Cr}$ content [8]. Furthermore, cyclocreatine is much more stable and is a superior long-acting phosphagen compared to $\mathrm{PCr}$, since it longer sustains ATP synthesis during ischaemia by continuously phosphorylating ADP [63]. Although cyclocreatine has yielded positive effect on brain deficits in CrT knock-out mice [64], in a cardiac ischaemia/reperfusion model [65] and in cardiac surgery with a cardioprotective effect [66], its use is limited by pharmacological off-target effects and by a lower affinity for CK compared to Cr. Moreover, since the use of cyclocreatine is limited by its water insolubility and the need to be administered much earlier than the ischemic event, a new soluble preparation has been proposed and needs further investigation [63]. 


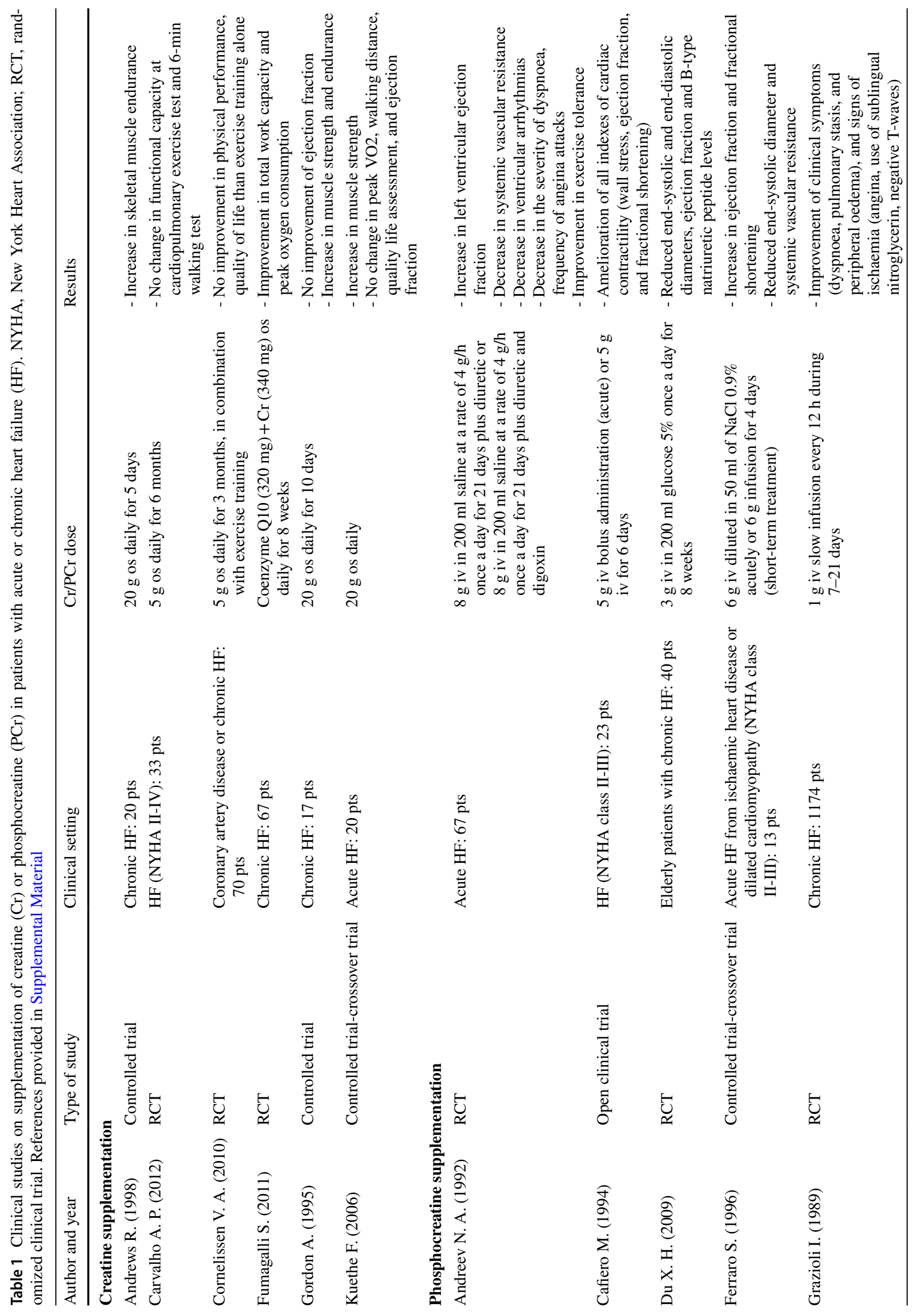




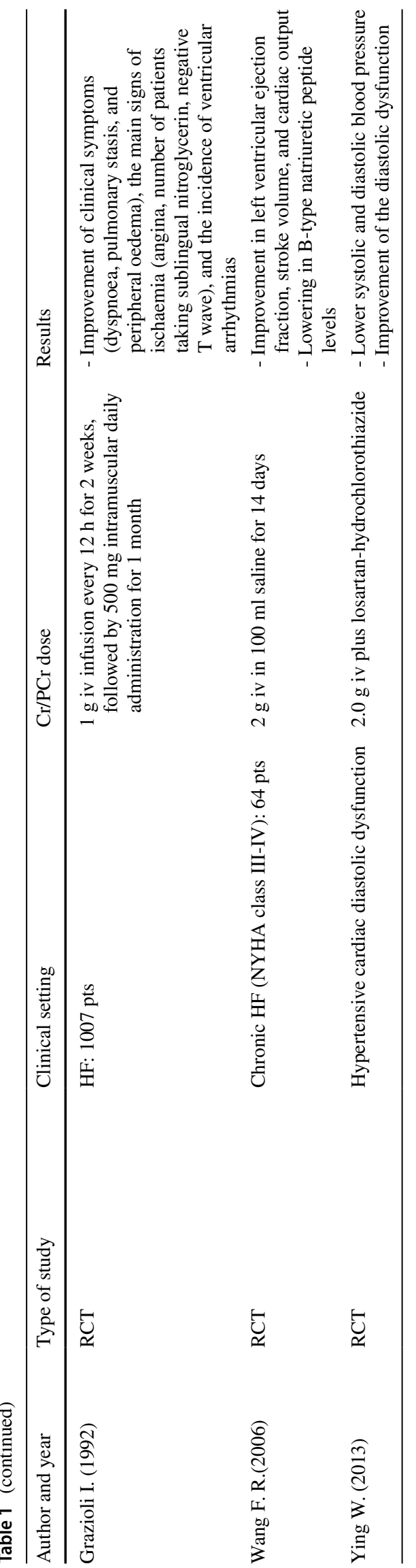

\section{Conclusions}

As a component of the energy buffer system, $\mathrm{Cr}$ is involved in cardiac metabolism to transfer energy from site of production to site of utilization. While a decreased cardiac $\mathrm{Cr}$ content is a feature of advanced HF, reduction in the rate of ATP synthesis through CK system might explain contractile dysfunction and poor outcomes in HF patients even in earlier stages. Nevertheless, the effects of $\mathrm{Cr}$ analogue and $\mathrm{PCr}$ supplementation are controversial and probably need to be tested in randomized studies on top of current pharmacological and non-pharmacological therapies. In this regard, cardiac MRS is expected to grow in importance, as it might estimate, in a non-invasive fashion, the energetic response to metabolic therapies and provide useful surrogate prognostic markers. Finally, future studies shall address $\mathrm{Cr}$ supplementation treatment only to $\mathrm{HF}$ patients with assessed $\mathrm{Cr}$ deficiency, by measuring the absorbed $\mathrm{Cr}$ content compared to the treatment dose.

\section{Central illustration}

Failing heart shows a decreased creatine $(\mathrm{Cr})$ content and creatine kinase (CK) activity, as well as a reduced expression of $\mathrm{Cr}$ transporter. Phosphocreatine/adenosine triphosphate ratio (PCr/ATP), an index of efficiency of cardiac energy metabolism, is also lower than normal value $(<1.60)$. Differently from $\mathrm{Cr}$ supplementation, treatment with PCr has showed to reduce short-term mortality, to improve left ventricular ejection fraction and to decrease the risk of major arrhythmias [61]. However, further investigation is needed for long-term treatment.

Supplementary information The online version contains supplementary material available at https://doi.org/10.1007/s10741-021-10173-y.

Funding Open access funding provided by Scuola Superiore Sant'Anna within the CRUI-CARE Agreement.

Data availability Not applicable.

Code availability Not applicable.

\section{Declarations}

Conflicts of interest The authors declare no competing interests.

Open Access This article is licensed under a Creative Commons Attribution 4.0 International License, which permits use, sharing, adaptation, distribution and reproduction in any medium or format, as long as you give appropriate credit to the original author(s) and the source, provide a link to the Creative Commons licence, and indicate if changes were made. The images or other third party material in this article are included in the article's Creative Commons licence, unless indicated 
otherwise in a credit line to the material. If material is not included in the article's Creative Commons licence and your intended use is not permitted by statutory regulation or exceeds the permitted use, you will need to obtain permission directly from the copyright holder. To view a copy of this licence, visit http://creativecommons.org/licenses/by/4.0/.

\section{References}

1. Wallimann T, Tokarska-Schlattner M, Schlattner U (2011) The creatine kinase system and pleiotropic effects of creatine. Amino Acids 40:1271-1296. https://doi.org/10.1007/ s00726-011-0877-3

2. Kaasik A, Veksler V, Boehm E, Novotova M, Minajeva A, Ventura-Clapier R (2001) Energetic crosstalk between organelles: architectural integration of energy production and utilization. Circ Res 89:153-159. https://doi.org/10.1161/hh1401. 093440

3. Wyss M, Kaddurah-Daouk R (2000) Creatine and creatinine metabolism. Physiol Rev 80:1107-1213. https://doi.org/10.1152/ physrev.2000.80.3.1107

4. Joncquel-Chevalier Curt M, Voicu PM, Fontaine M, Dessein AF, Porchet N, Mention-Mulliez K, Dobbelaere D, Soto-Ares G, Cheillan D, Vamecq J (2015) Creatine biosynthesis and transport in health and disease. Biochimie 119:146-165. https://doi.org/10. 1016/j.biochi.2015.10.022

5. Zervou S, Ray T, Sahgal N, Sebag-Montefiore L, Cross R, Medway DJ, Ostrowski PJ, Neubauer S, Lygate CA (2013) A role for thioredoxininteracting protein (Txnip) in cellular creatine homeostasis. Am J Physiol Endocrinol Metab 305:E263-E270. https://doi.org/10.1152/ ajpendo.00637.2012

6. Darrabie MD, Arciniegas AJL, Mishra R, Bowles DE, Jacobs DO, Santacruz L (2011) AMPK and substrate availability regulate creatine transport in cultured cardiomyocytes. Am J Physiol Endocrinol Metab 300:E870-E876. https://doi.org/10.1152/ajpendo. 00554.2010

7. ten Hove M, Makinen K, Sebag-Montefiore L, Hunyor I, Fischer A, Wallis J, Isbrandt D, Lygate C, Neubauer S (2008) Creatine uptake in mouse hearts with genetically altered creatine levels. J Mol Cell Cardiol 45:453-459. https://doi.org/10.1016/j.yjmcc. 2008.05.023

8. Zervou S, Whittington HJ, Russell AJ, Lygate CA (2016) Augmentation of creatine in the heart. Mini Rev Med Chem 16:19-28. https://doi.org/10.2174/1389557515666150722102151

9. Nascimben L, Ingwall JS, Pauletto P, Friedrich J, Gwathmey JK, Saks V, Pessina AC, Allen PD (1996) Creatine kinase system in failing and nonfailing human myocardium. Circulation 94:18941901. https://doi.org/10.1161/01.cir.94.8.1894

10. Guzun R, Timohhina N, Tepp K, Gonzalez-Granillo M, Shevchuk I, Chekulayev V, Kuznetsov AV, Kaambre T, Saks VA (2011) Systems bioenergetics of creatine kinase networks: physiological roles of creatine and phosphocreatine in regulation of cardiac cell function. Amino Acids 40:1333-1348. https://doi.org/10.1007/ s00726-011-0854-x

11. Neubauer S, Krahe T, Schindler R, Horn M, Hillenbrand H, Entzeroth C, Mader H, Kromer EP, Riegger GA, Lackner K (1992) 31P magnetic resonance spectroscopy in dilated cardiomyopathy and coronary artery disease. Altered cardiac high-energy phosphate metabolism in heart failure. Circulation 86:1810-8. https://doi.org/10.1161/01.cir. 86.6.1810

12. Weiss RG, Gerstenblith G, Bottomley PA (2005) ATP flux through creatine kinase in the normal, stressed, and failing human heart. Proc Natl Acad Sci U S A 102:808-813. https://doi.org/10.1073/ pnas.0408962102
13. Bottomley PA, Weiss RG (1998) Non-invasive magnetic-resonance detection of creatine depletion in non-viable infarcted myocardium. Lancet 351:714-718. https://doi.org/10.1016/S0140-6736(97) 06402-7

14. Bottomley PA (2016) MRS Studies of creatine kinase metabolism in human heart. eMagRes 5:1183-1202. https://doi.org/10.1002/ 9780470034590.emrstm1488

15. Hansch A, Rzanny R, Heyne JP, Leder U, Reichenbach JR, Kaiser WA (2005) Noninvasive measurements of cardiac high-energy phosphate metabolites in dilated cardiomyopathy by using 31P spectroscopic chemical shift imaging. Eur Radiol 15:319-323. https://doi.org/10.1007/s00330-004-2504-0

16. Beer M, Seyfarth T, Sandstede J, Landschütz W, Lipke C, Köstler H, von Kienlin M, Harre K, Hahn D, Neubauer S (2002) Absolute concentrations of high-energy phosphate metabolites in normal, hypertrophied, and failing human myocardium measured noninvasively with (31)P-SLOOP magnetic resonance spectroscopy. J Am Coll Cardiol 40:1267-1274. https://doi.org/10.1016/s07351097(02)02160-5

17. Ambrosio G, Jacobus WE, Bergman CA, Weisman HF, Becker LC (1987) Preserved high energy phosphate metabolic reserve in globally "stunned" hearts despite reduction of basal ATP content and contractility. J Mol Cell Cardiol 19:953-964. https://doi.org/ 10.1016/s0022-2828(87)80568-0

18. Gabr RE, El-Sharkawy AM, Schär M, Panjrath GS, Gerstenblith G, Weiss RG, Bottomley PA (2018) Cardiac work is related to creatine kinase energy supply in human heart failure: a cardiovascular magnetic resonance spectroscopy study. J Cardiovasc Magn Reson 20:81. https://doi.org/10.1186/s12968-018-0491-6

19. Bottomley PA, Panjrath GS, Lai S, Hirsch GA, Wu K, Najjar SS, Steinberg A, Gerstenblith G, Weiss RG (2013) Metabolic rates of ATP transfer through creatine kinase (CK Flux) predict clinical heart failure events and death. Sci Transl Med 5:215re3. https:// doi.org/10.1126/scitranslmed.3007328

20. Gupta A, Akki A, Wang Y, Leppo MK, Chacko VP, Foster DB, Caceres V, Shi S, Kirk JA, Su J, Lai S, Paolocci N, Steenbergen C, Gerstenblith G, Weiss RG (2012) Creatine kinase-mediated improvement of function in failing mouse hearts provides causal evidence the failing heart is energy starved. J Clin Invest 122:291302. https://doi.org/10.1172/JCI57426

21. Shen W, Vatner DE, Vatner SF, Ingwall JS (2010) Progressive loss of creatine maintains a near normal $\Delta \mathrm{G} \sim \mathrm{ATP}$ in transgenic mouse hearts with cardiomyopathy caused by overexpressing Gs $\alpha$. J Mol Cell Cardiol 48:591-599. https://doi.org/10.1016/j.yjmcc.2009. 10.029

22. Weiss K, Bottomley PA, Weiss RG (2015) On the theoretical limits of detecting cyclic changes in cardiac high-energy phosphates and creatine kinase reaction kinetics using in vivo ${ }^{31} \mathrm{P}$ MRS. NMR Biomed 28:694-705. https://doi.org/10.1002/nbm.3302

23. Ingwall JS (2009) Energy metabolism in heart failure and remodelling. Cardiovasc Res 81:412-419. https://doi.org/10.1093/cvr/cvn301

24. Ingwall JS, Weiss RG (2004) Is the failing heart energy starved? On using chemical energy to support cardiac function. Circ Res 95:135-145. https://doi.org/10.1161/01.RES.0000137170.41939.d9

25. Zhou B, Tian R (2018) Mitochondrial dysfunction in pathophysiology of heart failure. J Clin Invest 128:3716-3726. https://doi. org/10.1172/JCI120849

26. Lygate CA, Fischer A, Sebag-Montefiore L, Wallis J, ten Hove M, Neubauer S (2007) The creatine kinase energy transport system in the failing mouse heart. J Mol Cell Cardiol 42:1129-1136. https:// doi.org/10.1016/j.yjmcc.2007.03.899

27. Neubauer S, Horn M, Pabst T, Gödde M, Lübke D, Jilling B, Hahn D, Ertl G (1995) Contributions of 31P-magnetic resonance spectroscopy to the understanding of dilated heart muscle disease. Eur Heart J 16 Suppl O:115-8. https://doi.org/10.1093/eurheartj/ 16.suppl_o.115 
28. Neubauer S, Horn M, Cramer M, Harre K, Newell JB, Peters W, Pabst T, Ertl G, Hahn D, Ingwall JS, Kochsiek K (1997) Myocardial phosphocreatine-to-ATP ratio is a predictor of mortality in patients with dilated cardiomyopathy. Circulation 96:2190-2196. https://doi.org/10.1161/01.cir.96.7.2190

29. Neubauer S, Remkes H, Spindler M, Horn M, Wiesmann F, Prestle J, Walzel B, Ertl G, Hasenfuss G, Wallimann T (1999) Downregulation of the $\mathrm{Na}(+)$-creatine cotransporter in failing human myocardium and in experimental heart failure. Circulation 100:1847-1850. https://doi.org/10.1161/01.cir.100.18.1847

30. Mekhfi H, Hoerter J, Lauer C, Wisnewsky C, Schwartz K, Ventura-Clapier R (1990) Myocardial adaptation to creatine deficiency in rats fed with $\beta$-guanidinopropionic acid, a creatine analogue. Am J Physiol 258:H1151-H1158. https://doi.org/10.1152/ ajpheart.1990.258.4.H1151

31. Zweier JL, Jacobus WE, Korecky B, Brandejs-Barry Y (1991) Bioenergetic consequences of cardiac phosphocreatine depletion induced by creatine analogue feeding. J Biol Chem 266:2029620304 (PMID: 1939088)

32. Horn M, Remkes H, Strömer H, Dienesch C, Neubauer S (2001) Chronic phosphocreatine depletion by the creatine analogue beta-guanidinopropionate is associated with increased mortality and loss of ATP in rats after myocardial infarction. Circulation 104:1844-1849. https://doi.org/10.1161/hc3901.095933

33. Boehm EA, Radda GK, Tomlin H, Clark JF (1996) The utilisation of creatine and its analogues by cytosolic and mitochondrial creatine kinase. Biochim Biophys Acta 1274:119-128. https://doi. org/10.1016/0005-2728(96)00018-7

34. Lygate CA, Medway DJ, Ostrowski PJ, Aksentijevic D, SebagMontefiore L, Hunyor I, Zervou S, Schneider JE, Neubauer S (2012) Chronic creatine kinase deficiency eventually leads to congestive heart failure, but severity is dependent on genetic background, gender and age. Basic Res Cardiol 107:276. https://doi. org/10.1007/s00395-012-0276-2

35. Spindler M, Meyer K, Strömer H, Leupold A, Boehm E, Wagner $\mathrm{H}$, Neubauer S (2004) Creatine kinase-deficient hearts exhibit increased susceptibility to ischemia-reperfusion injury and impaired calcium homeostasis. Am J Physiol Heart Circ Physiol 287:H1039-H1045. https://doi.org/10.1152/ajpheart.01016.2003

36. Faller KME, Atzler D, McAndrew DJ, Zervou S, Whittington HJ, Simon JN, Aksentijevic D, Ten Hove M, Choe CU, Isbrandt D, Casadei B, Schneider JE, Neubauer S, Lygate CA (2018) Impaired cardiac contractile function in arginine:glycine amidinotransferase knockout mice devoid of creatine is rescued by homoarginine but not creatine. Cardiovasc Res 114:417-430. https://doi.org/10. $1093 / \mathrm{cvr} / \mathrm{cv} x 242$

37. ten Hove M, Lygate CA, Fischer A, Schneider JE, Sang AE, Hulbert K, Sebag-Montefiore L, Watkins H, Clarke K, Isbrandt D, Wallis J, Neubauer S (2005) Reduced inotropic reserve and increased susceptibility to cardiac ischemia/reperfusion injury in phosphocreatine-deficient guanidinoacetate-N-methyltransferaseknockout mice. Circulation 111:2477-2485. https://doi.org/10. 1161/01.CIR.0000165147.99592.01

38. Lygate CA, Aksentijevic D, Dawson D, ten Hove M, Phillips D, de Bono JP, Medway DJ, Sebag-Montefiore L, Hunyor I, Channon KM, Clarke K, Zervou S, Watkins H, Balaban RS, Neubauer S (2013) Living without creatine: unchanged exercise capacity and response to chronic myocardial infarction in creatine-deficient mice. Circ Res 112:945-955. https://doi.org/10.1161/CIRCRESAHA. 112.300725

39. Aksentijević D, Zervou S, Eykyn TR, McAndrew DJ, Wallis J, Schneider JE, Neubauer S, Lygate CA (2020) Age-dependent decline in cardiac function in guanidinoacetate-N-methyltransferase knockout mice. Front Physiol 10:1535. https://doi.org/10.3389/ fphys.2019.01535
40. Baroncelli L, Molinaro A, Cacciante F, Alessandrì MG, Napoli D, Putignano E, Tola J, Leuzzi V, Cioni G, Pizzorusso T (2016) A mouse model for creatine transporter deficiency reveals early onset cognitive impairment and neuropathology associated with brain aging. Hum Mol Genet 25:4186-4200. https://doi.org/10. 1093/hmg/ddw252

41. Lygate CA, Bohl S, ten Hove M, Faller KM, Ostrowski PJ, Zervou S, Medway DJ, Aksentijevic D, Sebag-Montefiore L, Wallis J, Clarke K, Watkins H, Schneider JE, Neubauer S (2012) Moderate elevation of intracellular creatine by targeting the creatine transporter protects mice from acute myocardial infarction. Cardiovasc Res 96:466-475. https://doi.org/10.1093/cvr/cvs272

42. Wallis J, Lygate CA, Fischer A, ten Hove M, Schneider JE, SebagMontefiore L, Dawson D, Hulbert K, Zhang W, Zhang MH, Watkins H, Clarke K, Neubauer S (2005) Supranormal myocardial creatine and phosphocreatine concentrations lead to cardiac hypertrophy and heart failure: insights from creatine transporter-overexpressing transgenic mice. Circulation 112:3131-3139. https://doi.org/10. 1161/CIRCULATIONAHA.105.572990

43. Belardinelli R, Georgiou D, Cianci G, Purcaro A (1999) Randomized, controlled trial of long-term moderate exercise training in chronic heart failure: effects on functional capacity, quality of life, and clinical outcome. Circulation 99:1173-1182. https://doi. org/10.1161/01.cir.99.9.1173

44. Kemi OJ, Høydal MA, Haram PM, Garnier A, Fortin D, VenturaClapier R, Ellingsen O (2007) Exercise training restores aerobic capacity and energy transfer systems in heart failure treated with losartan. Cardiovasc Res 76:91-99. https://doi.org/10.1016/j.cardiores.2007.06. 008

45. Hemati F, Rahmani A, Asadollahi K, Soleimannejad K, Khalighi Z (2016) Effects of complementary creatine monohydrate and physical training on inflammatory and endothelial dysfunction markers among heart failure patients. Asian J Sports Med 7:e28578. https:// doi.org/10.5812/asjsm.28578

46. Lopaschuk GD, Ussher JR, Folmes CD, Jaswal JS, Stanley WC (2010) Myocardial fatty acid metabolism in health and disease. Physiol Rev 90:207-258. https://doi.org/10.1152/physrev.00015. 2009

47. Wallhaus TR, Taylor M, DeGrado TR, Russell DC, Stanko P, Nickles RJ, Stone CK (2001) Myocardial free fatty acid and glucose use after carvedilol treatment in patients with congestive heart failure. Circulation 103:2441-2446. https://doi.org/10.1161/ 01.cir.103.20.2441

48. Bersin RM, Wolfe C, Kwasman M, Lau D, Klinski C, Tanaka K, Khorrami P, Henderson GN, de Marco T, Chatterjee K (1994) Improved hemodynamic function and mechanical efficiency in congestive heart failure with sodium dichloroacetate. J Am Coll Cardiol 23:1617-1624. https://doi.org/10.1016/0735-1097(94) 90665-3

49. Fragasso G (2016) Deranged cardiac metabolism and the pathogenesis of heart failure. Card Fail Rev 2:8-13. https://doi.org/10. 15420/cfr.2016:5:2

50. Kantor PF, Lucien A, Kozak R, Lopaschuk GD (2000) The antianginal drug trimetazidine shifts cardiac energy metabolism from fatty acid oxidation to glucose oxidation by inhibiting mitochondrial long-chain 3-ketoacyl coenzyme A thiolase. Circ Res 86:580-588. https://doi.org/10.1161/01.res.86.5.580

51. Fragasso G, Perseghin G, De Cobelli F, Esposito A, Palloshi A, Lattuada G, Scifo P, Calori G, Del Maschio A, Margonato A (2006) Effects of metabolic modulation by trimetazidine on left ventricular function and phosphocreatine/adenosine triphosphate ratio in patients with heart failure. Eur Heart J 27:942-948. https://doi.org/10.1093/eurheartj/ehi816

52. Sabbah HN, Chandler MP, Mishima T, Suzuki G, Chaudhry P, Nass O, Biesiadecki BJ, Blackburn B, Wolff A, Stanley WC 
(2002) Ranolazine, a partial fatty acid oxidation (pFOX) inhibitor, improves left ventricular function in dogs with chronic heart failure. J Card Fail 8:416-422. https://doi.org/10.1054/jcaf.2002. 129232

53. Gordon A, Hultman E, Kaijser L, Kristjansson S, Rolf CJ, Nyquist O, Sylvén C (1995) Creatine supplementation in chronic heart failure increases skeletal muscle creatine phosphate and muscle performance. Cardiovasc Res 30:413-418 (PMID: 7585833)

54. Santacruz L, Arciniegas AJL, Darrabie M, Mantilla JG, Baron RM, Bowles DE, Mishra R, Jacobs DO (2017) Hypoxia decreases creatine uptake in cardiomyocytes, while creatine supplementation enhances HIF activation. Physiol Rep 5:e13382. https://doi. org/10.14814/phy2.13382

55. Sciatti E, Lombardi C, Ravera A, Vizzardi E, Bonadei I, Carubelli V, Gorga E, Metra M (2016) Nutritional deficiency in patients with heart failure. Nutrients 8:442. https://doi.org/10.3390/nu8070442

56. Fumagalli S, Fattirolli F, Guarducci L, Cellai T, Baldasseroni S, Tarantini F, Di Bari M, Masotti G, Marchionni N (2011) Coenzyme Q10 terclatrate and creatine in chronic heart failure: a randomized, placebo-controlled, double-blind study. Clin Cardiol 34:211-217. https://doi.org/10.1002/clc.20846

57. Lombardi C, Carubelli V, Lazzarini V, Vizzardi E, Bordonali T, Ciccarese C, Castrini AI, Dei Cas A, Nodari S, Metra M (2015) Effects of oral administration of orodispersible levo-carnosine on quality of life and exercise performance in patients with chronic heart failure. Nutrition 31:72-78. https://doi.org/10.1016/j.nut. 2014.04.021

58. Cooper R, Naclerio F, Allgrove J, Jimenez A (2012) Creatine supplementation with specific view to exercise/sports performance: an update. J Int Soc Sports Nutr 9:33. https://doi.org/10.1186/ 1550-2783-9-33

59. Rector TS, Bank AJ, Mullen KA, Tschumperlin LK, Sih R, Pillai K, Kubo SH (1996) Randomized, double-blind, placebo-controlled study of supplemental oral L-arginine in patients with heart failure. Circulation 93:2135-2141. https://doi.org/10.1161/01.cir.93. 12.2135
60. Strumia E, Pelliccia F, D'Ambrosio G (2012) Creatine phosphate: pharmacological and clinical perspectives. Adv Ther 29:99-123. https://doi.org/10.1007/s12325-011-0091-4

61. Landoni G, Zangrillo A, Lomivorotov VV, Likhvantsev V, Ma J, De Simone F, Fominskiy E (2016) Cardiac protection with phosphocreatine: a meta-analysis. Interact Cardiovasc Thorac Surg 23:637-646. https://doi.org/10.1093/icvts/ivw171

62. Snow RJ, Murphy RM (2001) Creatine and the creatine transporter: a review. Mol Cell Biochem 224:169-181. https://doi.org/ 10.1023/a:1011908606819

63. Elgebaly SA, Poston R, Todd R, Helmy T, Almaghraby AM, Elbayoumi T, Kreutzer DL (2019) Cyclocreatine protects against ischemic injury and enhances cardiac recovery during early reperfusion. Expert Rev Cardiovasc Ther 17:683-697. https://doi.org/ 10.1080/14779072.2019.1662722

64. Cacciante F, Gennaro M, Sagona G, Mazziotti R, Lupori L, Cerri E, Putignano E, Butt M, Do MT, McKew JC, Alessandrì MG, Battini R, Cioni G, Pizzorusso T, Baroncelli L (2020) Cyclocreatine treatment ameliorates the cognitive, autistic and epileptic phenotype in a mouse model of Creatine Transporter Deficiency. Sci Rep 10:18361. https://doi.org/10.1038/s41598-020-75436-4

65. Osbakken M, Ito K, Zhang D, Ponomarenko I, Ivanics T, Jahngen EG, Cohn M (1992) Creatine and cyclocreatine effects on ischemic myocardium: 31P nuclear magnetic resonance evaluation of intact heart. Cardiology 80:184-195. https://doi.org/10.1159/000175002

66. Houser SL, Elkerm AF, Wei Z, Doyle K, Houser D, Liu XK, Tyles E, Kaddurah-Daouk R, Elgebaly SA (1995) Enhancement of cardiac function by cyclocreatine in models of cardiopulmonary bypass. J Mol Cell Cardiol 27:1065-1073. https://doi.org/10.1016/ 0022-2828(95)90075-6

Publisher's Note Springer Nature remains neutral with regard to jurisdictional claims in published maps and institutional affiliations. 